\title{
DAMPAK UKURAN PERUSAHAAN, KONSENTRASI KEPEMILIKAN DAN PROFITABILITAS TERHADAP PENGUNGKAPAN ASET BIOLOGIS
}

\author{
Tiara Riski ${ }^{1}$, Diyah Probowulan ${ }^{2}$, Retno Murwanti ${ }^{3}$ \\ 1,2,3 Program Studi Akuntansi Fakultas Ekonomi \\ Universitas Muhammadiyah Jember \\ e-mail: tiarariski1@gmail.com
}

\begin{abstract}
Abstrak
Penelitian ini bertujuan untuk mendapatkan bukti empiris tentang analisis faktor-faktor yang mempengaruhi pengungkapan aset biologis yang masih bersifat sukarela pada periode penelitian ini tetapi telah efektif pada Januari 2018 di perusahaan perkebunan di Indonesia. Faktor-faktor yang digunakan meliputi, ukuran perusahaan, konsentrasi kepemilikan, dan profitabilitas. Pengukuran pengungkapan aset biologis menggunakan analisis konten. Ada 36 item untuk mendeteksi tingkat pengungkapan aset biologis. Populasi penelitian ini adalah semua data keuangan perusahaan perkebunan yang terdaftar di BEI periode 2015-2018. Metode pengambilan sampel yang digunakan dalam penelitian ini adalah metode purposive sampling. Total sampel yang digunakan dalam penelitian ini adalah 36 sampel. Data yang digunakan adalah data sekunder dari Bursa Efek Indonesia. Teknik analisis yang digunakan adalah analisis regresi linier berganda. Hasil penelitian ini menunjukkan bahwa ukuran perusahaan tidak berpengaruh terhadap pengungkapan aset biologis, sedangkan konsentrasi kepemilikan dan profitabilitas berpengaruh terhadap pengungkapan aset biologis.
\end{abstract}

Kata kunci : Ukuran Perusahaan, Konsentrasi Kepemilikan, Profitabilitas dan Pengungkapan Aset Biologis.

\begin{abstract}
This study aims to obtain empirical evidence on the analysis of factors affecting biological asset disclosure which is still voluntary in the period of this research but has been effective as of January, 2018 in plantation firms in Indonesia. Factors used include, firm size, ownership concentration, and profitability. Measurement of biological asset disclosure using content analysis. There are 36 items to detect the level of biological asset disclosure. The population of this study is all financial data of plantation companies listed on the BEI period 2015-2018. Sampling method used in this research is purposive sampling method. The total samples used in this study were 36 samples. The data used is secondary data from Indonesia Stock Exchange. The analysis technique used is multiple linear regression analysis. The results of this study indicate that firm size have an no effect on biological asset disclosure, while ownership concentration and profitability have effect on biological asset disclosure.
\end{abstract}

Keywords : Firm Size, Ownership Concentration, Profitability and Biological Asset Disclosure. 


\section{PENDAHULUAN}

Indonesia merupakan negara yang beriklim tropis dan memiliki potensi sumber daya alam yang sangat besar. Sumber daya alam yang berlimpah akan berdampak pada beragamnya komoditas alam atau yang biasa disebut agrikultur. Dengan memanfaatkan sumber daya alam yang dimiliki, para petani Indonesia dapat menanam berbagai jenis agrikultur dan mengelola sehingga dapat mengambil manfaat dari hasil tersebut. Selain itu, agrikultur juga terbagi ke dalam beberapa sub sektor yaitu perkebunan, holtikultura, kehutanan, florikultura, perikanan dan peternakan (Trina, 2017).

Pada dasarnya pengelolaan keuangan aset biologis yang ada pada sektor perkebunan harus mengacu pada Standar Akuntansi Keuangan yang berlaku. Pada awal 2016 DSAK (Dewan Standar Akuntansi Keuangan) telah mengesahkan PSAK-69 agrikultur yang efektif diadopsi oleh seluruh perusahaan agrikultur pada 1 Januari 2018. Pengadopsian penuh dari IAS 41 Agriculture (International Accounting Standart) menjadi PSAK 69 berisi tentang perlakuan akuntansi untuk sektor agrikultur yang meliputi pengungkapan, penyajian, pengukuran dan pelaporan aset biologis. Maka dari itu, penyajian laporan keuangan harus disertai dengan pengungkapan yang berarti penyampaian berupa informasi. Pengungkapan adalah komunikasi informasi ekonomi yang dilakukan oleh perusahaan yang didalamnya mencakup informasi keuangan maupun non keuangan, informasi kuantitatif maupun informasi lain yang menggambarkan posisi dan kinerja perusahaan (Owusu, 1998).

Keterbukaan informasi perusahaan menjadi pemicu bagi berlangsungnya kehidupan perusahaan, terutama pada bagaimana ukuran perusahaan itu sendiri. Semakin besar ukuran perusahaan maka semakin tinggi pula tuntutan terhadap keterbukaan informasinya. Dalam penelitian sebelumnya yang dilakukan oleh (Goncalves \& Lopes, 2014) memperoleh hasil bahwa ukuran perusahaan berpengaruh terhadap pengungkapan aset biologis.

Darmawati (2006) menyatakan semakin terkonsentrasinya kepemilikan perusahaan, maka pemegang saham mayoritas akan semakin menguasai perusahaan dan semakin berpengaruh terhadap pengambilan keputusan. Hasil dari penelitian Nuryaman (2009) dan Goncalves \& Lopes (2014) menyimpulkan bahwa konsentrasi kepemilikan berpengaruh terhadap tingkat pengungkapan, berbeda dengan penelitian Amelia (2016) menemukan hasil bahwa konsentrasi kepemilikan tidak berpengaruh terhadap pengungkapan aset biologis.

Profitabilitas menjadi menjadi salah satu informasi yang banyak digunakan oleh para investor. Perusahaan yang memiliki kinerja keuangan yang baik biasanya di ukur berdasarkan tingkat profitabilitasnya. Semakin baik profitabilitas perusahaan maka semakin tinggi pula return yang diterima perusahaan. Penelitian (Nugroho, 2012) menyatakan bahwa profitabilitas berpengaruh positif terhadap pengungkapan, namun berbeda dengan penelitian (Sefani, 2012) yang menyatakan bahwa profitabilitas berpengaruh negatif terhadap pengungkapan informasi dan (Duwu, 2018) menyatakan dalam penelitiannya bahwa profitabilitas tidak berpengaruh signifikan terhadap pengungkapan aset biologis.

Alasan peneliti memilih item pengungkapan aset biologis, dikarenakan ingin melihat apakah semua perusahaan agrikultur pada sub sektor perkebunan yang ada di Indonesia sudah mengungkapkan seluruh aset biologis yang dikelola. Berdasarkan hal tersebut maka peneliti tertarik untuk meneliti "Dampak Ukuran Perusahaan, Konsentrasi Kepemilikan dan Profitabilitas Terhadap Pengungkapan Aset Biologis (Pada Perusahaan Perkebunan yang terdaftar di Bursa Efek Indonesia Periode 2015-2018)".

Berdasarkan latar belakang diatas, maka rumusan masalah yang diambil adalah "Bagaimana Dampak Ukuran Perusahaan, Konsentrasi Kepemilikan Dan Profitabilitas Terhadap Pengungkapan Aset Biologis Pada Perusahaan Perkebunan Yang Terdaftar Di Bursa Efek Indonesia Periode 2015-2018?"

Berdasarkan rumusan masalah yang ada, maka rumusan masalah penelitian adalah sebagai berikut:

1. Apakah ukuran perusahaan berpengaruh terhadap pengungkapan aset biologis pada perusahaan perkebunan yang terdaftar di Bursa Efek Indonesia periode 2015-2018?

2. Apakah konsentrasi kepemilikan berpengaruh terhadap pengungkapan aset biologis pada perusahaan perkebunan yang terdaftar di Bursa Efek Indonesia periode 2015-2018?

3. Apakah profitabilitas berpengaruh terhadap pengungkapan aset biologis pada perusahaan perkebunan yang terdaftar di Bursa Efek Indonesia periode 2015-2018 ? 
Dari rumusan masalah di atas maka tujuan yang ingin dicapai dari penelitian ini adalah :

1. Untuk mengetahui apakah ukuran perusahaan berpengaruh terhadap pengungkapan aset biologis pada perusahaan perkebunan yang terdaftar di Bursa Efek Indonesia periode 2015-2018?

2. Untuk mengetahui apakah konsentrasi kepemilikan berpengaruh terhadap pengungkapan aset biologis pada perusahaan perkebunan yang terdaftar di Bursa Efek Indonesia periode 2015-2018?

3. Untuk mengetahui apakah profitabilitas berpengaruh terhadap pengungkapan aset biologis pada perusahaan perkebunan yang terdaftar di Bursa Efek Indonesia periode 2015-2018?

Penelitian ini diharapkan dapat dijadikan referensi bagi manajemen untuk pertimbangan dalam memperhatikan pengungkapan aset biologis pada perusahaan.

Penelitian ini diharapkan dapat menambah pengetahuan dan pengalaman mengenai akuntansi keuangan khususnya mengenai pengaruh ukuran perusahaan, konsentrasi kepemilikan dan profitabilitas terhadap pengungkapan aset biologis, serta sebagai salah satu syarat untuk menyelesaikan program S1 Akuntansi Fakultas Ekonomi dan Bisnis Universitas Muhammadiyah Jember.

Diharapkan dapat mendukung pengembangan teori untuk memperluas ilmu akuntansi khususnya dibidang akuntansi keuangan mengenai dampak biological asset intensity, ukuran perusahaan, konsentrasi kepemilikan dan profitabilitas terhadap pengungkapan aset biologis.

Menurut PSAK 69 aset biologis adalah hewan dan tanaman hidup. Karakteristik khusus yang melekat pada aset biologis terletak pada adanya transformasi atau perubahan biologis atas aset ini sampai pada aset dikonsumsi lebih lanjut (Safitri, 2013).

Berdasarkan definisi diatas, dapat disimpulkan bahwa aset biologis adalah aset yang dimiliki perusahaan yang bergerak dalam sektor agrikultur berupa tanaman dan hewan ternak yang memiliki karakteristik berbeda dari aset lainnya karena adanya transformasi biologis dari aset tersebut.

Menurut (Jogiyanto Hartono, 2015) pengertian ukuran perusahaan adalah: "Ukuran aktiva digunakan untuk mengukur besarnya perusahaan, ukuran aktiva tersebut diukur sebagai logaritma total aktiva".
Maka dapat disimpulkan bahwa ukuran perusahaan merupakan ukuran atas besar kecilnya aset yang dimiliki perusahaan karena perusahaan besar umumnya memiliki total aset yang besar pula dan sebaliknya, apabila perusahaan tersebut berskala kecil umumnya memiliki total aset yang juga kecil.

Konsentrasi kepemilikan (ownership concentration) adalah suatu ukuran atas distribusi kekuasaan pengambilan keputusan (voting power distribution) baik untuk para pemilik atau para manajer. Gunarsih (2004) menyatakan bahwa kepemilikan perusahaan merupakan salah satu mekanisme yang dapat dipergunakan agar pengelola melakukan aktivitas sesuai dengan kepentingan pemilik perusahaan.

Perusahaan yang memiliki kinerja keuangan yang baik biasanya di ukur berdasarkan tingkat profitabilitasnya. Profitabilitas merupakan salah satu faktor yang menjadi pusat perhatian investor, perusahaan dengan profitabilitas yang tinggi akan memiliki sumber daya keuangan yang lebih besar sehingga akan mendorong manajemen perusahaan untuk mengungkapkan informasi selain yang diwajibkan. Seiring dengan tingginya profitabilitas akan muncul biaya politik dikarenakan profitabilitas perusahaan yang tinggi dapat menarik perhatian media dan konsumen (Duwu, 2018).

Pengungkapan secara teknis didefinisikan sebagai langkah akhir dalam proses akuntansi yaitu penyajian informasi dalam bentuk seperangkat penuh statemen keuangan. Secara umum, pengungkapan merupakan konsep, metode dan media tentang bagaimana informasi akuntansi disampaikan kepada pihak yang berkepentingan (Suwardjono, 2014).

Berdasarkan pengertian diatas, pengungkapan adalah informasi yang tercantum dalam laporan perusahaan yang berisi laporan keuangan maupun informasi lain yang mencerminkan bagaimana kondisi dan kinerja perusahaan.

Menurut (Suwardjono, 2014) tujuan dari pengungkapan adalah sebagai berikut: "Tujuan pengungkapan adalah menyajikan informasi yang dipandang perlu untuk mencapai tujuan pelaporan keuangan dan untuk melayani berbagai pihak yang mempunyai kepentingan berbeda-beda. Faktanya bahwa investor dan kreditur tidak homogen tetapi bervariasi dalam hal kecanggihannya. Karena pasar modal merupakan sarana utama penampung dana dari masyarakat, pengungkapan dapat 
diwajibkan untuk tujuan melindungi, informatif dan melayani kebutuhan khusus.

Berdasarkan PSAK 69 Agrikultur (2018:43), pengungkapan aset yang dilakukan entitas adalah:

"Pengungkapan deskriptif kuantitatif aset biologis dibedakan menjadi aset biologis yang dapat dikonsumsi dan aset produktif (bearer biological asset), atau aset biologis yang menghasilkan (mature) dan yang belum menghasilkan (immature). Sebagai contoh, entitas dapat mengungkapkan jumlah tercatat aset biologis yang dapat dikonsumsi dan aset biologis produktif berdasarkan kelompok.

Berikut merupakan kerangka konseptual yang peneliti gunakan untuk mengetahui dampak Ukuran Perusahaan $\left(\mathrm{X}_{1}\right)$, Konsentrasi Kepemilikan $\left(\mathrm{X}_{2}\right)$, dan Profitabilitas $\left(\mathrm{X}_{3}\right)$ terhadap Pengungkapan Aset Biologis $(\mathrm{Y})$.

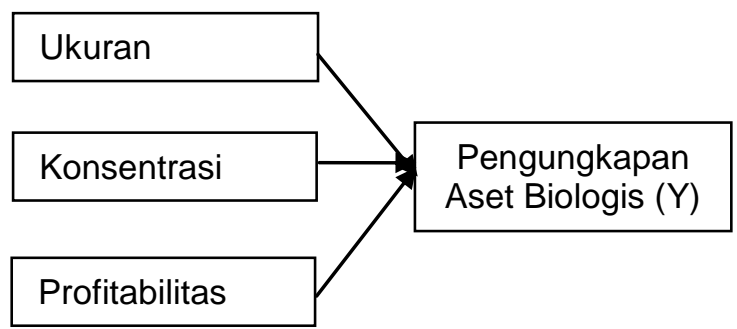

Gambar 1 Kerangka Konseptual

\section{Keterangan :}

\section{= Hubungan Parsial}

Berdasarkan kerangka konseptual diatas, maka hipotesis yang diajukan dalam penelitian ini adalah sebagai berikut:

Menurut (Nuryaman, 2009) semakin besar perusahaan maka perusahaan akan menghadapi tuntutan lebih besar dari para stakeholder untuk menyaikan laporan keuangan yang lebih transparan. Dari hasil penelitian tersebut (Nuryaman, 2009) menyimpulkan bahwa ukuran perusahaan berpengaruh terhadap tingkat pengungkapan.

Penelitian yang dilakukan oleh (Amelia, 2016) memperoleh hasil bahwa ukuran perusahaan berpengaruh positif signifikan terhadap pengungkapan aset biologis. Hasil penelitian yang sama juga diperoleh (Duwu, 2018) bahwa ukuran perusahaan juga berpengaruh terhadap pengungkapan aset biologis. Dari uraian diatas hipotessis kedua yang akan diuji dalam penelitian ini adalah sebagai berikut:

\section{H1: Ukuran perusahaan berpengaruh terhadap pengungkapan aset biologis.}

Konsentrasi

kepemilikan

menggambarkan bagaimana dan siapa saja yang memegang kendali atas keseluruhan atau sebagian besar atas kepemilikan perusahaan serta keseluruhan atau sebagian besar pemegang kendali atas aktivitas bisnis pada suatu perusahaan (Taman dan Nugroho, 2012). Jadi disimpulkan bahwa konsentrasi kepemilikan merupakan sekelompok pengendali atas aktivitas bisnis perusahaan.

Darmawati (2006) menyatakan bahwa semakin terkonsentrasinya kepemilikan suatu perusahaan, maka pemegang saham mayoritas akan semakin menguasai perusahaan serta semakin berpengaruh terhadap pengambilan keputusan. Hasil penelitian (Nuryaman, 2009) menemukan bahwa konsentrasi kepemilikan memiliki pengaruh terhadap tingkat pengungkapan. Beda halnya dengan penelitian (Amelia, 2016) dan (Duwu, 2018) yang menyimpulkan bahwa konsentrasi kepemilikan tidak berpengaruh terhadap pengungkapan aset biologis. Dari uraian tersebut hipotesis ketiga yang akan diuji dalam penelitian ini adalah sebagai berikut:

\section{H2: Konsentrasi kepemilikan berpengaruh terhadap pengungkapan aset biologis.}

Menurut (Sartono, 2010), Profitabilitas mencerminkan keuntungan dari investasi keuangan serta menggambarkan kemampuan perusahaan di dalam menghasilkan laba. Perusahaan yang menghasilkan laba atau profitabilitas biasanya akan melakukan pengungkapan yang lebih banyak karena manajemen perusahaan ingin meyakinkan seluruh pengguna laporan keuangan bahwa kinerja perusahaan bagus dan berada pada posisi persaingan yang kuat. Dari hasil penelitian yang dilakukan oleh (Nugroho, 2012) menyatakan bahwa profitabilitas berpengaruh positif terhadap pengungkapan informasi dalam laporan keuangan tahunan. Berbeda dengan penelitian yang dilakukan oleh (Sefani, 2012) yang menyimpulkan hasil bahwa profitabilitas berpengaruh negatif terhadap pengungkapan informasi. Dari uraian tersebut hipotesis keempat yang akan diuji dalam penelitian ini adalah sebagai berikut: H3 : Profitabilitas berpengaruh terhadap
pengungkapan aset biologisMETODE 


\section{METODE}

\begin{abstract}
Menurut
(Sugiyono,

2017)

mendefinisikan metode penelitian yaitu: "Metode penelitian adalah cara ilmiah untuk mendapatkan data dengan tujuan dan kegunaan tertentu. Cara ilmiah berarti kegiatan penelitian ini didasarkan pada ciri-ciri keilmuan yaitu rasional, empiris dan sistematis. Rasional berarti kegiatan penelitian yang dilakukan dengan cara-cara yang dilakukan itu dapat diminati oleh indra manusia sehingga orang lain dapat mengamati dan mengetahui caracara yang digunakan. Sistematis artinya proses yang digunakan dalam penelitian ini meggunakan langkah-langkah tertentu yang logis".
\end{abstract}

Jenis penelitian ini merupakan penelitian kuantitatif, yaitu penelitian yang bertujuan untuk mengetahui pengaruh antara dua variabel atau lebih. Jenis data yang digunakan dalam penelitian ini adalah kuantitatif. Sedangkan sumber data yang digunakan dalam penelitian ini yaitu menggunakan data sekunder. Data sekunder yang digunakan berupa laporan tahunan perusahaan perkebunan 2015 sampai dengan tahun 2018 yang terdaftar di Bursa Efek Indonesia (BEI). Data tersebut diperoleh dari website Bursa Efek Indonesia (www.idx.go.id).

Dalam penelitian ini populasi yang digunakan adalah seluruh perusahaan perkebunan yang terdaftar di Bursa Efek Indonesia periode 2015-2018.

Sampel yang saya pilih dari populasi perusahaan berdasarkan purposive sampling. Pemilihan sampel dengan metode purposive sampling menggunakan kriteria sebagai berikut: 1) Perusahaan perkebunan yang terdaftar di Bursa Efek Indonesia periode 2015-2018, 2) Perusahaan perkebunan yang menerbitkan laporan keuangan dan laporan tahunan pada periode 2015-2018, 3) Perusahaan perkebunan yang mengunakan mata uang rupiah, dan 4) Perusahaan perkebunan yang memiliki laba positif.

Dalam penelitian ini pengumpulan data yang digunakan yaitu teknik dokumentasi yaitu teknik atau cara untuk mengumpulkan data dengan mempelajari dan mencatat bagian bagian yang dianggap penting. Dokumentasi yang dimaksud dalam penelitian ini berupa sampel laporan tahunan perusahaan subsektor perkebunan yang terdaftar di Bursa Efek Indonesia periode 2015-2018.

Selain metode dokumentasi, penelitian ini menggunakan penelitian kepustakaan (library research), yaitu dengan mengumpulkan data-data dari sumber-sumber pustaka yang mendukung penelitian.

Ukuran perusahaan merupakan ukuran atas besar kecilnya aset yang dimiliki perusahaan sehingga perusahaan besar umumnya mempunyai total aktiva yang besar pula dan sebaliknya apabila perusahaan kecil umumnya memiliki total aktiva yang kecil. Ukuran perusahaan dapat dihitung dengan Logaritma natural dari total aktiva yang dirumuskan sebagai berikut:

\section{Ukuran Perusahaan $($ Size $)=L n$ Total Aset}

Dalam teori klasik managerial firm, terdapat dua tipe kepemilikan dan kontrol suatu perusahaan. Yang pertama yaitu perusahaan yang dimiliki oleh banyak pemegang saham, yang kedua yaitu perusahaan dimiliki serta dikontrol oleh manajemen (Duwu, 2018). Dalam penelitian ini menggunakan konsentrasi kepemilikan perusahaan yang di kontrol oleh manajemen. dihitung menggunakan rumus sebagai berikut:

Konsentrasi Kepemilikan $=\frac{\text { Jumlah Kepemilikan Saham Terbesar }}{\text { Jumlah Saham Beredar }} \times 100$

\subsubsection{Profitabilitas}

Pada penelitian ini profitabilitas diproksikan dengan Return On Asset (ROA) menggunakan rasio untuk menilai perusahaan dalam mencari keuntungan dan menunjukkan tingkat efektifitas manajemen suatu perusahaan. Hal ini ditunjukkan oleh laba yang dihasilkan dari penjualan dan pendapatan investasi. ROA dapat dihitung menggunakan:

$$
\mathrm{ROA}=\frac{\text { Laba Bersih Setelah Pajak }}{\text { Total Aset }}
$$

Pengungkapan aset biologis merupakan variabel dependen yang digunakan dalam penelitian ini. Item pengungkapan aset biologis terdapat dalam appendix 1. Indeks pengungkapan untuk mengukur luas pengungkapan aset biologis yaitu dengan memberi skor 1 (satu) pada setiap item yang diungkap dalam laporan keuangan yang telah diaudit, dan memberi skor 0 (nol) jika tidak diungkapkan. Pengukuran luas pengungkapan aset biologis menggunakan rumus indeks Wallace sebagai berikut:

$$
\text { Indeks }=n / k \times 100 \%
$$


Keterangan:

$\mathrm{n}=$ total skor yang diperoleh

36 = total skor yang diwajibkan menurut PSAK 69

Berdasarkan jenis data dan analisis, penelitian ini adalah jenis penelitian kuantitatif. Dalam melakukan analisis terhadap data yang akan dikumpulkan, maka perhitungan pengolahan dan penganalisaan dilakukan dengan bantuan dari program SPSS (Statistical Product and Service Solution) untuk meregresikan model yang telah dirumuskan.

Analisis statistik deskriptif akan dihitung dari masing-masing sampel yang ada dan digunakan untuk mengetahui gambaran umum tentang apa saja yang mempengaruhi perusahaan dalam melakukan pengungkapan aset biologis.

Uji normalitas digunakan untuk menguji apakah distribusi variabel terikat untuk setiap nilai variabel bebas tertentu berdistribusi normal atau tidak. Dalam model regresi linier, asumsi ini ditunjukkan oleh nilai error yang berdistribusi normal atau mendakati normal, sehingga layak dilakukan pengujian secara statistik. Pengujian normalitas data menggunakan Test Normality KolmogorovSmirnov dalam program SPSS.

Menurut Singgih Santoso (2012: 393) dasar pengambilan keputusan dapat dilakukan dengan melihat angka probabilitasnya, yaitu:

a. Jika probabilitas $>0,05$ maka distribusi dari model regresi adalah normal.

b. Jika probabilitas $<0,05$ maka distribusi dari model regresi adalah tidak normal.

Dalam penelitian ini menggunakan persamaan regresi linier berganda karena variabel bebas dalam penelitian ini lebih dari satu. Adapun persamaan regresi linier berganda menurut Sugiyono (2017:275) dirumuskan sebagai berikut:

$$
Y=a+b_{1} X_{1}+b_{2} X_{2}+b_{3} X_{3}+e
$$

Keterangan :

$$
\begin{array}{lll}
\mathrm{Y} & =\quad \text { Variabel dependen } & \text { untuk } \\
& \text { Pengungkapan Aset Biologis } \\
\mathrm{a} & =\text { Konstanta (nilai } \mathrm{Y} \text { apabila } \mathrm{X}_{1}, \mathrm{X}_{2} \ldots \mathrm{Xn}=0 \text { ) } \\
\mathrm{b}_{1} & =\text { Koefisien Regresi untuk } \mathrm{X}_{1} \\
\mathrm{X}_{1} & =\text { Variabel independen untuk Ukuran } \\
& \text { Perusahaan } \\
\mathrm{b}_{2} & =\text { Koefisien Regresi untuk } \mathrm{X}_{2} \\
\mathrm{X}_{2} & =\text { Variabel independen untuk Konsentrasi } \\
& \text { Kepemilikan } \\
\mathrm{b}_{3} & =\text { Koefisien Regresi untuk } \mathrm{X}_{3} \\
\mathrm{X}_{3} & =\text { Variabel independen untuk Profitabilitas } \\
\mathrm{e} & =\text { Eror }
\end{array}
$$

$\begin{array}{ccc}\text { Menurut } & \text { Ghozali (2013), uji } \\ \text { multikolinieritas bertujuan untuk menguji }\end{array}$ apakah model regresi ditemukan adanya kolerasi antar variabel independen (bebas). Model regresi yang baik seharusnya tidak terjadi kolerasi diantara variabel independen (bebas). Jika variabel independen saling berkolerasi, maka variabel-variabel ini tidak orthogonal. Variabel orthogonal adalah variabel independen yang nilai kolerasi antar semua variabel independen sama dengan nol.

Untuk mendeteksi ada tidaknya multikolinieritas dapat dilihat pada besaran Variance Inflation Factor (VIF) dan Tolerance. Pedoman suatu model regresi yang bebas multikolinieritas adalah mempunyai angka tolerance mendekati 1, batas VIF adalah 10, jika nilai VIF dibawah 10, maka tidak terjadi gejala multikolinieritas.

Menurut (Singgih Santoso, 2012), rumus yang digunakan adalah sebagai berikut:

$$
\mathrm{VIF}=\frac{1}{\text { Tolerance }} \text { atau Tolerance }=\frac{1}{\mathrm{VIF}}
$$

Salah satu cara untuk mendeteksi ada atau tidaknya heterokedastisitas adalah dengan menggunakan grafik Scatterplot antara nilai prediksi variavel terikat (dependen) yaitu ZPRED dengan residualnya SRESID. Dengan cara melihat grafik flot antara nilai prediksi variabel terikat dengan residualnya dasar analisis sebagai berikut:

1) Jika ada pola tertentu, seperti titik-titik yang ada membentuk pola tertentu secara teratur (bergelombang, melebar kemudian menyempit), maka mengindikasikan telah terjadi heteroskedastisitas.

2) Jika tidak adapola yang jelas, serta titik-titik menyebar di atas dan di bawah angka nol pada sumbu $\mathrm{Y}$, maka tidak terjadi heteroskedastisitas.

Pengujian ini dilakukan untuk menunjukkan seberapa jauh pengaruh satu variabel independen secara individual dalam menerangkan variasi variabel dependen (Ghozali, 2016). Uji t merupakan salah satu uji hipotesis penelitian dalam analisis regresi linier sederhana maupun analisis regresi linier berganda. Uji t bertujuan untuk mengetahui apakah variabel independen (X) secara parsial (sendiri-sendiri) berpengaruh terhadap variabel dependen $(\mathrm{Y})$.

Menurut (Kurniawan, 2014) dalam penelitian (Kusumadewi, 2018) Koefisien determinasi dapat dirumuskan sebagai berikut 


$$
\mathbf{K D}=\mathbf{R}^{2} \times 100 \%
$$

KD : Koefisien determinasi.

$\mathrm{R}^{2} \quad$ : Koefisien korelasi yang dikuadratkan.

Nilai koefisien determinasi berkisar antara 0 sampai 1 apabila nilai koefisien determinasi mendekati 1 artinya pengaruh variabel independen (ukuran perusahaan, konsentrasi kepemilikan dan profitabilitas) terhadap variabel dependen (pengungkapan aset biologis) semakin kuat dan sebaliknya apabila nilai koefisien determinasi mendekati 0 maka pengaruh variabel independen terhadap variabel dependen semakin lemah (Nawari, 2010).

Tabel 1 Hasil Statistik Deskriptif

\section{HASIL DAN PEMBAHASAN}

\section{Gambaran Umum Objek Penelitian}

Penelitian ini menggunakan sampel perusahaan perkebunan yang terdaftar di Bursa Efek Indonesia (BEI) periode 2015-2018 agar lebih menggambarkan kondisi yang terjadi saat ini. Jumlah perusahaan perkebunan yang terdaftar di Bursa Efek Indonesia (BEI) selama periode 2015-2018 yaitu sebanyak 16 perusahaan perkebunan pada setiap tahunnya. Penentuan sampel dalam penelitian ini yaitu menggunakan teknik purposive sampling dan diperoleh sampel sebanyak 36 yang sesuai dengan kriteria penelitian.

\begin{tabular}{llllll}
\hline & N & Min & Max & Mean & Std. Deviation \\
\hline Ukuran Perusahaan & 36 & 15,88 & 23,15 & 18,6039 & 2,86332 \\
Konsentrasi Kepemilikan & 36 & 25,05 & 98,01 & 65,0758 & 19,39993 \\
Profitabilitas & 36 &, 02 & 9,86 & 4,4881 & 2,76813 \\
Pengungkapan Aset Biologis & 36 & 30,56 & 47,22 & 39,1972 & 4,82300 \\
Valid N (listwise) & 36 & & & & \\
\hline
\end{tabular}

Berdasarkan Tabel 1 dapat diketahui bahwa jumlah sampel yang digunakan dalam penelitian ini yaitu sebanyak 36 sampel penelitian. Variabel dependen yaitu Pengungkapan Aset Biologis memiliki nilai minimum sebesar 30,56, memiliki nilai maksimum 47,22, memiliki rata-rata (mean) sebesar 39,1972 dan standar deviasi (simpangan baku) sebesar 4,82300. Variabel independen yaitu Ukuran Perusahaan memiliki nilai minimum sebesar 15,88 memiliki nilai

Tabel 2. Hasil Uji Normalitas

\begin{tabular}{lll}
\hline & & Unstandardized Residual \\
\hline $\mathrm{N}$ & & 36 \\
Normal Parameters $^{\mathrm{a}, \mathrm{b}}$ & Mean &, 0000000 \\
& Std. Deviation & 4,14280785 \\
& Absolute &, 081 \\
Most Extreme Differences & Positive &, 041 \\
& Negative &,- 081 \\
Kolmogorov-Smirnov Z & &, 483 \\
Asymp. Sig. (2-tailed) & &, 974 \\
\hline
\end{tabular}

Sumber: Hasil Olah Data 2019

Berdasarkan Tabel 2 menunjukkan hasil uji normalitas one- sample KolmogorovSmirnov test (KS) dengan model unstandardized memperoleh hasil 0,974 maksimum 23,15 , memiliki nilai rata-rata sebesar 18,6039 dan standar deviasi sebesar 2,86332. Variabel Konsentrasi Kepemilikan memiliki nilai minimum sebesar 25,05, memiliki nilai maksimum 98,01 , nilai rata-rata sebesar 65,0758 dan standar deviasi sebesar 19,39993. Variabel Profitabilitas memiliki nilai minimum sebesar 0,02 , memiliki nilai maksimum 9,86 , nilai rata rata sebesar 4,4881 dan 
Tabel 3. Hasil Analisis Regresi Linier Berganda

\begin{tabular}{|c|c|c|c|c|c|c|}
\hline \multirow{3}{*}{\multicolumn{2}{|c|}{ Model }} & \multirow{2}{*}{\multicolumn{2}{|c|}{$\begin{array}{l}\text { Unstandardized } \\
\text { Coefficients }\end{array}$}} & \multirow{3}{*}{$\begin{array}{l}\text { Standardized } \\
\text { Coefficients } \\
\text { Beta }\end{array}$} & \multirow{3}{*}{$\mathrm{t}$} & \multirow{3}{*}{ Sig. } \\
\hline & & & & & & \\
\hline & & $\mathrm{B}$ & Std. Error & & & \\
\hline \multirow[t]{4}{*}{1} & (Constant) & 37,775 & 6,188 & & 6,104 & ,000 \\
\hline & Ukuran Perusahaan & ,232 & ,263 & ,138 & ,883 & ,384 \\
\hline & $\begin{array}{l}\text { Konsentrasi } \\
\text { Kepemilikan }\end{array}$ &,- 086 & ,038 &,- 347 & $-2,259$ & ,031 \\
\hline & Profitabilitas & ,606 & ,269 & ,348 & 2,252 & ,031 \\
\hline
\end{tabular}

Dari persamaan tersebut dapat diartikan bahwa:

1. Konstanta sebesar 37,775 menunjukkan besarnya luas pengungkapan aset biologis pada ukuran perusahaan, konsentrasi kepemilikan dan profitabilitas sama dengan nol.

2. Untuk koefisien regresi ukuran perusahaan terhadap pengungkapan 1 aset biologis memberikan pengaruh sebesar 0,232 .

3. Untuk koefisien regresi konsentrasi kepemilikan terhadap pengungkapan aset biologis memberikan pengaruh sebesar 0,086 .

4. Untuk koefisien regresi profitabilitas terhadap pengungkapan aset biologis memberikan pengaruh sebesar 0,606.

5. $\mathrm{e}=6,188$ artinya besarnya kesalahan dalam model regresi.

Tabel 4. Hasil Uji Multikolinieritas

\begin{tabular}{lllc}
\hline Model & & \multicolumn{2}{c}{ Collinearity Statistics } \\
\hline 1 & (Constant) & Tolerance & VIF \\
& Ukuran Perusahaan & & \\
& Konsentrasi Kepemilikan &, 945 & 1,058 \\
& Profitabilitas &, 976 & 1,025 \\
& &, 966 & 1,035 \\
\hline & \multicolumn{2}{c}{ Sumber: Hasil Olah Data 2019 }
\end{tabular}

Berdasarkan Tabel 4 menunjukkan bahwa nilai tolerance untuk semua variabel independen dalam penelitian ini $>0,10$ dan nilai variance inflation factor (VIF) untuk semua variabel independen dalam penelitian ini < 10 sehingga dapat disimpulkan bahwa model regresi dalam penelitian ini tidak terjadi multikolinearitas.

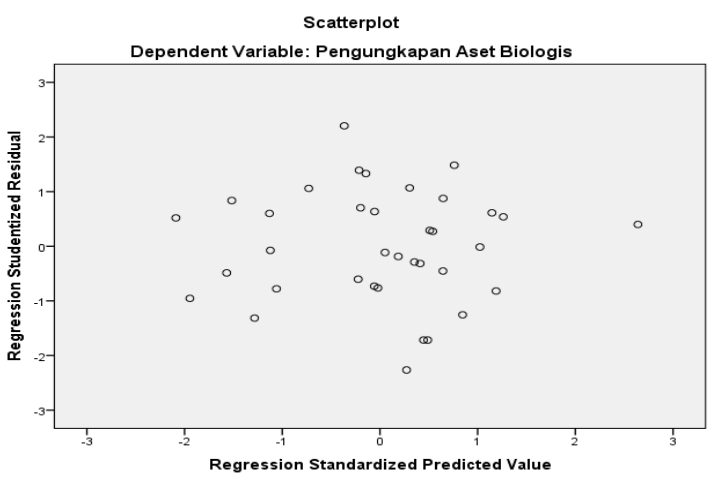

Gambar 1. Grafik Scatterplot

Berdasarkan gambar scatterplot diatas, menandakan tidak ada pola tertentu, seperti titik-titik yang ada tidak membentuk pola tertentu secara teratur (bergelombang, melebar kemudian menyempit), maka mengindikasikan tidak terjadi heteroskedastisitas, kemudian tidak ada pola yang jelas, serta titik-titik menyebar di atas dan di bawah angka nol pada sumbu $Y$, maka tidak terjadi heteroskedastisitas pada penelitian ini. 
Tabel 5. Hasil Uji Statistik t

\begin{tabular}{|c|c|c|c|c|c|c|}
\hline \multirow[t]{2}{*}{ Model } & & \multicolumn{2}{|c|}{$\begin{array}{l}\text { Unstandardized } \\
\text { Coefficients }\end{array}$} & \multirow{2}{*}{$\begin{array}{l}\text { Standardized } \\
\text { Coefficients } \\
\text { Beta }\end{array}$} & \multirow[t]{2}{*}{$\mathrm{t}$} & \multirow[t]{2}{*}{ Sig. } \\
\hline & & $B$ & Std. Error & & & \\
\hline$\overline{1}$ & $\begin{array}{l}\text { (Constant) } \\
\text { Ukuran Perusahaan } \\
\text { Konsentrasi Kepemilikan } \\
\text { Profitabilitas }\end{array}$ & $\begin{array}{l}37,775 \\
, 232 \\
-, 086 \\
, 606\end{array}$ & $\begin{array}{l}6,188 \\
, 263 \\
, 038 \\
, 269\end{array}$ & $\begin{array}{l}, 138 \\
-, 347 \\
, 348\end{array}$ & $\begin{array}{l}6,104 \\
, 883 \\
-2,259 \\
2,252\end{array}$ & $\begin{array}{l}, 000 \\
, 384 \\
, 031 \\
, 031\end{array}$ \\
\hline
\end{tabular}

Berdasarkan hasil output uji statistik $t$ diatas maka dapat diuraikan sebagai berikut :

\section{Pengujian Hipotesis 1}

Berdasarkan Tabel 4.6 variabel ukuran perusahaan memiliki nilai sig sebesar 0,384. Tingkat signifikansi variabel ukuran perusahaan lebih besar dari alpha 0,05 sehingga dapat dikatakan bahwa ukuran perusahaan tidak berpengaruh terhadap pengungkapan aset biologis. Dengan demikian maka hipotesis pertama $(\mathrm{H} 1)$ yang menjelaskan bahwa ukuran perusahaan berpengaruh positif terhadap pengungkapan aset biologis ditolak.

\section{Pengujian Hipotesis 2}

Berdasarkan Tabel 4.6 variabel konsentrasi kepemilikan memiliki nilai sig sebesar 0,031. Tingkat signifikansi variabel konsentrasi kepemilikan lebih kecil dari alpha 0,05 sehingga dapat dikatakan bahwa konsentrasi kepemilikan berpengaruh terhadap pengungkapan aset biologis. Dengan demikian maka hipotesis pertama $(\mathrm{H} 2)$ yang menjelaskan bahwa konsentrasi kepemilikan berpengaruh positif terhadap pengungkapan aset biologis diterima.

\section{Pengujian Hipotesis 3}

Berdasarkan Tabel 4.6 variabel profitabilitas memiliki nilai sig sebesar 0,031. Tingkat signifikansi variabel profitabilitas lebih kecil dari alpha 0,05 sehingga dapat dikatakan bahwa profitabilitas berpengaruh terhadap pengungkapan aset biologis. Dengan demikian maka hipotesis pertama $(\mathrm{H} 2)$ yang menjelaskan bahwa profitabilitas berpengaruh positif terhadap pengungkapan aset biologis diterima.

Tabel 6. Hasil Uji Koefisien Determinasi

\begin{tabular}{lllllc}
\hline Model & $\mathrm{R}$ & $\mathrm{R}$ Square & $\begin{array}{l}\text { Adjusted } \\
\text { Square }\end{array}$ & $\begin{array}{l}\text { RStd. Error of theDurbin-Watson } \\
\text { Estimate }\end{array}$ & \\
\hline 1 &, $512^{\mathrm{a}}$ &, 262 &, 193 & 4,33265 &, 863 \\
\hline
\end{tabular}

Sumber: Hasil Olah Data 2019

Berdasarkan hasil uji koefisien determinasi tersebut, menunjukkan bahwa nilai Adjusted $R$ Square sebesar 0,193 artinya variabel dependen (pengungkapan aset biologis) dapat dijelaskan oleh variabel independen (ukuran perusahaan, konsentrasi kepemilikan dan profitabilitas) sebesar 19\%, sedangkan sisanya $81 \%$ dipengaruhi oleh variabel lain di luar variabel penelitian ini.

Berdasarkan hasil uraian uji hipotesis yang telah dijelaskan sebelumnya, maka dapat disimpulkan dan diringkas ke dalam Tabel 4.8 sebagai berikut:

Tabel 7. Hasil Ringkasan Hipotesis

\begin{tabular}{llc}
\hline KODE & HIPOTESIS & KETERANGAN \\
\hline H1 & $\begin{array}{l}\text { Ukuran perusahaan berpengaruh positif terhadap } \\
\text { pengungkapan aset biologis } \\
\text { K2 }\end{array}$ & Konsentrasi kepemilikan berpengaruh positif \\
terhadap pengungkapan aset biologis & Diterima \\
H3 & Profitabilitas berpengaruh positif terhadapDiterima
\end{tabular}


Penelitian ini adalah hipotesis pertama (H1) ditolak. Berdasarkan perhitungan tersebut, peneliti menduga bahwa perusahaan perkebunan yang memiliki total aset dalam jumlah yang besar tidak menjamin akan memberikan pengungkapan aset biologis yang lebih luas dibandingkan dengan perusahaan perkebunan yang memiliki total aset yang lebih kecil. Perusahaan perkebunan yang memiliki total aset yang kecil juga memiliki kepentingan yang sama dengan perusahaan perkebunan yang memiliki total aset besar, yaitu untuk memperoleh tambahan modal dari pihak luar. Oleh sebab itu, perusahaan perkebunan yang memiliki total aset kecil akan tetap mengungkapan aset biologisnya minimal untuk menyamai perusahaan-perusahaan besar agar dapat memenangkan persaingan.

Perusahaan perkebunan baik itu perusahaan yang berukuran besar, menengah maupun perusahaan kecil tidak berpengaruh terhadap pengungkapan aset biologis. Bagi pihak eksternal terutama investor sebelum mengambil keputusan untuk menanamkan modalnya ke perusahaan perkebunan tidak menjadikan ukuran perusahaan sebagai tolok ukur dalam pengambilan keputusan untuk menanamkan modalnya.

Berdasarkan Tabel 4.8 menunjukkan bahwa hipotesis kedua $(\mathrm{H} 2)$ diterima. Penelitian ini membuktikan bahwa konsentrasi kepemilikan berpengaruh terhadap pengungkapan aset biologis yang dilakukan oleh perusahaan perkebunan yang terdaftar di Bursa Efek Indonesia (BEI) periode 20152018.

Pengungkapan aset biologis yang luas tersebut, yang disebabkan oleh adanya pengaruh konsentrasi kepemilikan yang dapat menarik perhatian berbagai pihak terutama investor. Investor akan menjadikan hal tersebut sebagai pusat perhatian dan bahan pertimbangan dalam mengambil keputusan untuk menanamkan modalnya ke perusahaan agrikultur tersebut.

Hasil dari penelitian ini menunjukkan bahwa hipotesis ketiga $(\mathrm{H} 3)$ diterima. Berdasarkan hasil perhitungan tersebut, diperoleh hasil bahwa profitabilitas berpengaruh terhadap pengungkapan aset biologis. Peneliti menduga bahwa tinggi atau rendahnya tingkat profitabilitas perusahaan perkebunan berpengaruh terhadap keluasan pengungkapan aset biologis.

Perusahaan perkebunan yang memiliki profitabilitas yang tinggi menjamin memberikan pengungkapan aset biologis secara luas dibandingkan dengan perusahaan perkebunan yang memiliki tingkat profitabilitas yang rendah. Oleh sebab itu, pengaruh profitabilitas perkebunan terhadap pengungkapan aset biologis yang dilakukan oleh perusahaan tersebut menjadi pusat perhatian bagi investor dalam mengambil keputusan investasi.

\section{PENUTUP}

Penelitian ini bertujuan untuk menguji dan mendapatkan bukti secara empiris mengenai pengaruh ukuran perusahaan, konsentrasi dan profitabilitas terhadap pengungkapan aset biologis. Sampel yang digunakan dalam penelitian ini adalah sampel dari perusahaan perkebunan yang terdaftar di Bursa Efek Indonesia (BEI) periode 20152018. Berdasarkan hasil penelitian dan pembahasan, maka dapat disimpulkan sebagai berikut:

Ukuran perusahaan tidak berpengaruh terhadap pengungkapan aset biologis pada perusahaan perkebunan yang terdaftar di Bursa Efek Indonesia (BEI) pada tahun 20152018.

Konsentrasi kepemilikan perusahaan berpengaruh terhadap pengungkapan aset biologis pada perusahaan perkebunan yang terdaftar di Bursa Efek Indonesia (BEI) pada tahun 2015-2018.

Profitabilitas berpengaruh positif terhadap pengungkapan aset biologis pada perusahaan perkebunan yang terdaftar di Bursa Efek Indonesia (BEI) pada tahun 20152018.

Berdasarkan penelitian yang telah dilakukan oleh peneliti, maka saran yang dapat diberikan dari penelitian ini adalah sebagai berikut:

Penelitian selanjutnya dapat menggunakan variabel lain seperti leverage agar lebih luas lagi dalam meneliti pengungkapan aset biologis.

Bagi penelitian selanjutnya dapat menggunakan periode tahun terbaru dan memperpanjang tahun pengamatan penelitian, dengan demikian dapat memberikan gambaran terkini untuk pengungkapan aset biologis.

Perusahaan perkebunan diharapkan lebih rinci dalam mengungkapkan aset biologis yang dikelola oleh perusahaannya. Pengungkapan secara rinci tersebut dimulai dari pengungkapan awal, masa panen, diproduksi menjadi produk agrikultur, hingga aset tersebut mengalami penghentian karena mati atau tidak berkembang biak lagi. Hal tersebut perlu dilakukan agar 
pemakai laporan keuangan dapat mengetahui secara rinci dan jelas.

Peneliti hanya menguji variabel ukuran perusahaan, konsentrasi kepemilikan dan profitabilitas dalam penelitian ini.

Penelitian ini memiliki nilai $\mathrm{R}$ Square yang rendah (19\%). Hal ini menunjukkan bahwa terdapat variabel lain yang tidak digunakan dalam penelitian ini yang memiliki pengaruh besar terhadap pengungkapan aset biologis.

Periode pengamatan masih terlalu pendek yaitu dari 2015-2018.

\section{DAFTAR PUSTAKA}

Alfiani, L. K. 2019. Pengaruh Biological Asset Intensity, Ukuran Perusahaan, Pertumbuhan Perusahaan, Konsentrasi Kepemilikan Manajerial, Dan Jenis Kap Terhadap Pengungkpan Aset Biologis.

Amelia, F. (2016). Pengaruh Biological Asset Intensity, Ukuran Perusahaan, Konsentrasi Kepemilikan dan Jenis KAP terhadap Pengungkapan Aset Biologis.

Aprianingsih, A. 2016. "Pengaruh Penerapan Good Corporate Governance, Struktur Kepemilikan, Dan Ukuran Perusahaan terhadap Kinerja Keuangan Perbankan". Jurnal Profita, Vol 11 (2).

Brigham dan Houston. 2010. Dasar-dasar Manajemen Keuangan Buku 1 (Edisi 11). Jakarta: Salemba Empat

Christiawan, Y. J. dan Tarigan, J. 2007. "Kepemilikan Manajerial: Kebijakan Hutang, Kinerja dan Nilai Perusahaan". Jurnal Akuntansi dan Keuangan. Vol 9 (1).

Darmawati, Deni. 2006. "Effect of Company Characteristics and Regulatory Factors of Quality Implementation of Good Corporate Governance". Accounting National Symposium IX. 23 to 26 December 2006. Padang.

Duwu, M. I., Daat, S. C., \& Andriati, H. N. (2018). Pengaruh Biological Asset Intensity, Ukuran Perusahaan, Konsentrasi Kepemilikan, Jenis Kap, Dan Profitabilitas Terhadap Biological Asset Disclosure. Jurnal Akuntansi Dan Keuangan Daerah, 13(2), 56-75.

Frida, A., Yurniawati, Dan Amsal Djunid. 2017. Pengaruh Biological Asset Intensity,
Ukuran Perusahaan, Konsentrasi Kepemilikan, Dan Jenis Kap Terhadap Pengungkapan Aset Biologis (Pada Perusahaan Agrikultur Yang Terdaftar Di Bursa Efek Indonesia Periode 20122015). Jurnal Simposium Nasional Akuntansi Xx. Jember

Ghozali, I. 2016. Aplikasi Analisis Multivariate Lanjutan dengan Program SPSS. Semarang: Badan Penerbitan Universitas Diponogoro.

Ghozali, Imam. 2013. Aplikasi Analisis Multivariate Dengan Program Ibm Spss 21 Update Pls Regresi. Edisi 7. Semarang: Badan Penerbit Undip . 2016. Aplikasi Analisis Multivariate Lanjutan Dengan Program Spss. Semarang: Badan Penerbitan Universitas Diponogoro

Goncalves, Rute, Dan Patrcia Lopes. 2014. Firm Spesific Determinants Of Agricultural Financial Reporting. University Of Porto, Vol 110 H. 470-481

Gunarsih, Tri. 2004. "Masalah Keagenan Dan Stratedi Diversifikasi." Jurnal Kompak, No. 10, H.52-69

Harahap, Sofyan Syafri. 2007. Analisis Kriteria Laporan Keuangan. Jakarta: Raja Grafindo Persada

Hartono, Jogianto. 2015. Teori Portofolio Dan Analisis Investasi. Jakarta: Rajawali Pers

Ikatan Akuntansi Indonesia (lai). 2018. Pernyataan Standar Akuntansi Keuangan (Psak) No.69: Agrikultur, Jakarta: lai

Kusumadewi, A. A. (2018). Pengaruh Biological Asset Intensity Dan Ukuran Perusahaan Terhadap Pengungkapan Aset Biologis (Pada Perusahaan Perkebunan Yang Terdaftar Di Bei Periode 2017) (Doctoral Dissertation, Perpustakaan Fakultas Ekonomi Dan Bisnis Unpas Bandung).

Nawari. 2010. Analisis Regresi dengan MS Excel 2007 dan SPSS 17. Jakarta: PT Elex Medi Komputindo.

Nazaruddin, I. dan Basuki, A. T. 2017. Analisis Statistik Dengan SPSS. Yogyakarta: Danisa Media. 
Nugroho, W. A. 2012. Pengaruh Profitabilitas, Likuiditas, dan Leverage terhadap Nilai Perusahaan (Studi pada Perusahaan Manufaktur Di BEI Periode 2008-2011). Jurnal Universitas Muhammadiyah Surakarta. pp: 30-55.

Nuryaman, N. (2009). Pengaruh Konsentrasi Kepemilikan, Ukuran Perusahaan, Dan Mekanisme Corporate Governance Terhadap Pengungkapan Sukarela. Jurnal Akuntansi Dan Keuangan Indonesia, 6(1), 89-116.

Owusu - Ansah, S. (1998). The Impact Of Corporate Attributes On The Extent Of Mandatory Disclosure And Reporting By Listed Companies In Zimbabwe.

Putri, D.G.S (2012). Analisis Akuntansi Atas Biological Asset Perusahaan Perkebunan Tanaman Keras Di Pt Asg Sebagai Studi Kasus. Skripsi, Jurusan Eksistensi Fakulyas Ekonomi Universitas Indonesia.

Ratih, K., D., P. 2018. Pengaruh Faktor Firm Level Terhadap Pengungkapan Perusahaan Perkebunan Terdaftar Di BEI Tahun 2012-2016. Skripsi. Universitas Andalas.

Safitri, Syamsi. 2013. Perlakuan Akuntansi Aset Biologis Hubungannya Dengan Kualitas Informasi Keuangan Pada Perkebunan Nusantara Vi Jambi (Persero). Jurnal Penelitian Akuntansi Fakultas Ekonomi Yptk Padang.

Santoso, Singgih. 2012. Analisis SPSS pada Statistika Parametrik. Jakarta: PT Elex Media Komputindo

Sartono, A. 2010. Manajemen Keuangan: Teori dan Aplikasi. Edisi keempat. Yogyakarta: BPFE

\section{Sefani. (2011). Faktor-Faktor Yang Mempengaruhi Kelengkapan Pengungkapan Laporan Keuangan Pada Perusahaan Manufaktur Yang Terdaftar Di Bei.}

Simanjuntak, H Binsar dan Lusy Widiastuti. (2004). Faktor-Faktor Yang Mempengaruhi Kelengkapan Pengungkapan Laporan Keuangan Pada Perusahaan Manufaktur Yang Terdaftar di BEJ. Jurnal Riset Akuntansi Indonesia, Vol. 7 No. Hal 351-366.
Sugiyono. 2017. Metode Penelitian Kuantitatif, Kualitatif Dan R\&D. Bandung: Alfabeta

Suwardjono. 2014. Teori Akuntansi Perekayasaan Pelaporan Keuangan, Edisi Ketiga Cetakan Kedelapan.Yogyakarta: Bpfe Yogyakarta

Trina, Z.I. (2017). Analisis Perlakuan Akuntansi Dan Deplesi Aset Biologis Berdasarkan las 41 Pada Perusahaan Peternakan : Studi Kasus Pada Cv. Milkindo Berka Abadi Kapanjen. Skripsi, Jurusan Akuntansi Fakultas Ekonomi Universitas Islam Negeri (Uin) Maulana Malik Ibrahim Malang, Malang.

Utomo, R. Dan Khumaidah, N.L. (2014). Perlakuan Akuntansi Aset Biologis (Tanaman Kopi) Pada Pt. Wahana Graha Makmur - Surabaya. Gema Ekonomi Jurnal Fakultas Ekonomi, Vol. 3, No.1.

Yurniwati, Y., Djunid, A., \& Amelia, F. (2018). Effect Of Biological Asset Intensity, Company Size, Ownership Concentration, And Type Firm Against Biological Assets. The Indonesian Journal Of Accounting Research, 21(1). 